\title{
Response to Lee et al .
}

Citation for published version (APA):

van Tol, R. R., Kimman, M. L., Melenhorst, J., Stassen, L. P. S., Dirksen, C. D., \& Breukink, S. O. (2019). Response to Lee et al . Colorectal Disease, 21(10), 1211-1212. https://doi.org/10.1111/codi.14791

Document status and date:

Published: 01/10/2019

DOI:

10.1111/codi.14791

Document Version:

Publisher's PDF, also known as Version of record

Document license:
Taverne

\section{Please check the document version of this publication:}

- A submitted manuscript is the version of the article upon submission and before peer-review. There can be important differences between the submitted version and the official published version of record.

People interested in the research are advised to contact the author for the final version of the publication, or visit the DOI to the publisher's website.

- The final author version and the galley proof are versions of the publication after peer review.

- The final published version features the final layout of the paper including the volume, issue and page numbers.

Link to publication

\footnotetext{
General rights rights.

- You may freely distribute the URL identifying the publication in the public portal. please follow below link for the End User Agreement:

www.umlib.nl/taverne-license

Take down policy

If you believe that this document breaches copyright please contact us at:

repository@maastrichtuniversity.nl

providing details and we will investigate your claim.
}

Copyright and moral rights for the publications made accessible in the public portal are retained by the authors and/or other copyright owners and it is a condition of accessing publications that users recognise and abide by the legal requirements associated with these

- Users may download and print one copy of any publication from the public portal for the purpose of private study or research.

- You may not further distribute the material or use it for any profit-making activity or commercial gain

If the publication is distributed under the terms of Article $25 \mathrm{fa}$ of the Dutch Copyright Act, indicated by the "Taverne" license above, 


\section{Methodology in core outcome sets}

doi:10.1111/codi.14744

Dear Sir, We read with interest the recent proposal for a core outcome set (COS) for haemorrhoidal disease by van Tol et al. [1]. We were very pleased to see this work as there is a definite need for the standardization of outcomes to facilitate comparison of studies and to prevent research wastage. We do have some of concerns about the methodology used, however.

1 Clinician involvement: This is a study developed with the support of the European Society of Coloproctology, a large and pan-European society. Despite this, only 17 clinicians completed round 1 of the study. There is a burden that goes with completion of surveys and we recognize this as a limit of the method. By comparison, the recent COS for Crohn's anal fistula secured responses from 120 clinicians in round 1 of responses [2]. The point of this comparison is that the outcomes ranked by clinicians in the latter study are likely to be more reflective of clinician opinion than the limited sample in the former.

2 Patient involvement: Typically COS development includes some focus group or qualitative work [3]. In this study, the patient involvement is limited to replying to a questionnaire developed by clinicians which focuses on symptomatology, with no apparent 'white-space' questions. This effectively excludes other items that may be important to patients such as procedure-related pain, recovery time, time off work and treatment-related costs. We assert that patient involvement, as key stakeholders, is essential in the development of COSs for benign disease. We do concede that the authors have identified this as a weakness of the study design.

3 Primacy of outcomes: As far as we are aware, COSs are meant to ensure that a selection of key items is collected and reported to avoid bias in reporting [3]. The authors of this study have gone a step further and proposed primary and secondary outcomes. We are not aware of this step being taken in other COS development studies in surgery $[2,4]$. We believe that patient-focused outcomes are important; however, there are study designs where a non-patient-reported outcome measure would be appropriate as the primary measure, e.g. cost-effectiveness studies. The authors would unnecessarily constrain the field if they were to push for widespread adoption of this set.
4 Measurement selection: Finally, the authors propose a list of tools to measure the outcomes they have recommended. The process driving the selection of tools is not clear in this study, and should be subject to a separate 'core outcome measurement' development study. If a measurement tool is proposed for outcomes in a set, then we would expect that a range of measures has been considered. Factors for consideration include different forms of validity, reliability and responsiveness. Without such considerations, an unreliable tool might impede the measurement of outcomes.

In summary, we think the intention behind this study is good. However, we would encourage those considering similar work in the future to consider the above issues to ensure a valid and relevant COS is developed.

\section{Lee* iD, D. Hind $\dagger$ and S. Brown*}

*Northern General Hospital, Sheffield, UK, and $\dagger$ Clinical Trials Research Unit, University of Sheffield, Sheffield, UK

E-mail: m.j.lee@sheffield.ac.uk

Received 26 May 2019; accepted 28 May 2019; Accepted Article Online 29 June 2019

\section{References}

I van Tol RR, Kimman ML, Melenhorst J et al. European Society of Coloproctology Core Outcome Set for haemorrhoidal disease: an international Delphi study among healthcare professionals. Colorectal Dis 2019; 21: 570-80.

2 Sahnan K, Tozer PJ, Adegbola SO et al. Developing a core outcome set for fistulising perianal Crohn's disease. Gut 2019; 68: 226-38.

3 Williamson PR, Altman DG, Blazeby JM et al. Developing core outcome sets for clinical trials: issues to consider. Trials 2012; 13: 132 .

4 Avery KNL, Chalmers KA, Brookes ST et al. Development of a core outcome set for clinical effectiveness trials in esophageal cancer resection surgery. Ann Surg 2018; 267: $700-10$.

\section{Response to Lee et al.}

doi:10.1111/codi.14791

\section{Dear Editor,}

Thank you for the opportunity to respond to the comments of Lee and colleagues. We appreciate their concerns and agree fully that appropriate methodology to ensure the relevance and validity of a Core Outcome 
Set (COS) is of great importance. We generally agree with their comments, of which most were acknowledged in our paper.

First, clinicians are key stakeholders when developing a COS for haemorrhoidal disease (HD), and inclusion of a representative sample of clinicians with relevant expertise is important. Initially, we contacted the 43 international representatives of the European Society of Coloproctology (ESCP) to participate in development of the COS. However, most representatives did not treat $\mathrm{HD}$ or felt that they were not experienced enough to provide input to the COS. Following their recommendations, we invited, using the so-called snowball method, health-care professionals with an in-depth understanding of HD and/or development of a COS to contribute. This strategy resulted in a smaller group of experts than initially planned, and we do consider this a limitation, which we acknowledged in the discussion section of our paper. However, the clinicians included still represented multiple European countries; in our opinion, and also the fact that no guidance exists regarding the minimum sample size of a stakeholder group, this approach produced valid views in an area in which experienced research professionals are limited.

Second, partial patient involvement in development of this first COS for HD was discussed as a limitation. Furthermore, a point highlighted in the title of our paper. Future editions of a COS for HD should indeed ensure a more prominent role of the patients.

Third, this COS focussed on a clinical research setting (i.e. clinical effectiveness studies) and for this reason we felt that it was appropriate (and consensus was reached) for use on core primary and secondary outcomes. We agree that in some contexts (a cost-effectiveness analysis, for example) other outcomes also may be relevant. We would like to emphasize that a COS represents the minimum set of outcomes to be collected in a clinical trial. Therefore, in our discussion we recommend that additional outcomes may be included if appropriate for the specific intervention or setting.

Finally, ideally one would follow the recommended methodology for selecting instruments for the outcomes of a COS [1]. However, the instruments selected for our COS were consensus-based and are the most widely used and validated instruments in the field. Uptake of a COS could be promoted by proposing it together with a suggestion for additional instruments.

Future work should address these issues to ensure a valid and relevant COS for HD. Hence, in our paper, we emphasized that a COS is a dynamic instrument and should regularly be reviewed.

\section{R. R. van Tol*, M. L. Kimman†, J. Melenhorst*, L. P. S. Stassen*, C. D. Dirksen $\dagger$ and S. O. Breukink*}

*Department of Surgery and Colorectal Surgery, Maastricht University Medical Center, Maastricht, The Netherlands, and †Department of

Clinical Epidemiology and Medical Technology Assessment, Maastricht University Medical Center, Maastricht, The Netherlands

E-mail: robin.van.tol@mumc.nl

Received 25 June 2019; accepted 9 July 2019; Accepted Article online 26 July 2019

\section{Reference}

I Williamson PR, Altman DG, Bagley $\mathrm{H}$ et al. The COMET Handbook: version 1.0. Trials 2017; 18(Suppl 3): 280.

\section{Comment on 'The Association of Colo- proctology of Great Britain and Ireland consensus guidelines in surgery for inflammatory bowel disease'}

doi:10.1111/codi.14787

Dear Editor,

I represent the Patient Liaison Group working with the Association of Coloproctology of Great Britain and Ireland (ACPGBI) particularly on the topic of inflammatory bowel disease (IBD). I took great pleasure in reading through the recently published guidelines [1].

From a patient's perspective, the issue of the ACPGBI consensus guidelines on surgery for IBD is a wonderful indicator of the collaboration that exists, not only between surgeons sharing their knowledge and expertise, but also between the surgeons and the gastroenterologists. The IBD Surgical Guidelines have been commissioned by ACPGBI to sit alongside the review by the British Society of Gastroenterology of the medical guidelines for the measurement of IBD [2]. This collaboration is most reassuring for patients and may encourage them to discuss the possibilities and options of surgery, alongside medical interventions, when considering treatment for their IBD.

The method of choosing which guidelines to use was also thought through very carefully and only those who had consensus between the authors at a high level were included. The surgeons involved spanned a wide range of specializations within bowel surgery and are highly regarded within their field and their peers. Also included amongst the authors were members of the ACPGBI's Patient Liaison Group who were invited to read the document and comment where their experience or knowledge allowed and so patients can be assured that their voice has been heard in the setting out of the guidelines. 